\title{
Notes on the vocalizations of Thrush-like Wren (Campylorhynchus turdinus)
}

Peter Boesman

In the following we briefly analyze and compare voice of the three races of Thrush-like Wren (Campylorhynchus turdinus). We also try to quantify the extent of any vocal differences using the criteria proposed by Tobias et al. (2010), as a support for taxonomic review. We have made use of sound recordings available on-line from Xeno Canto (XC).

Commonest song-like vocalizations are a repeated short phrase (often duet) of several lowpitched downslurred notes, and short almost clock-like ventriloquial notes given e.g. alternating at two different pitches, with several variations.

Some examples:

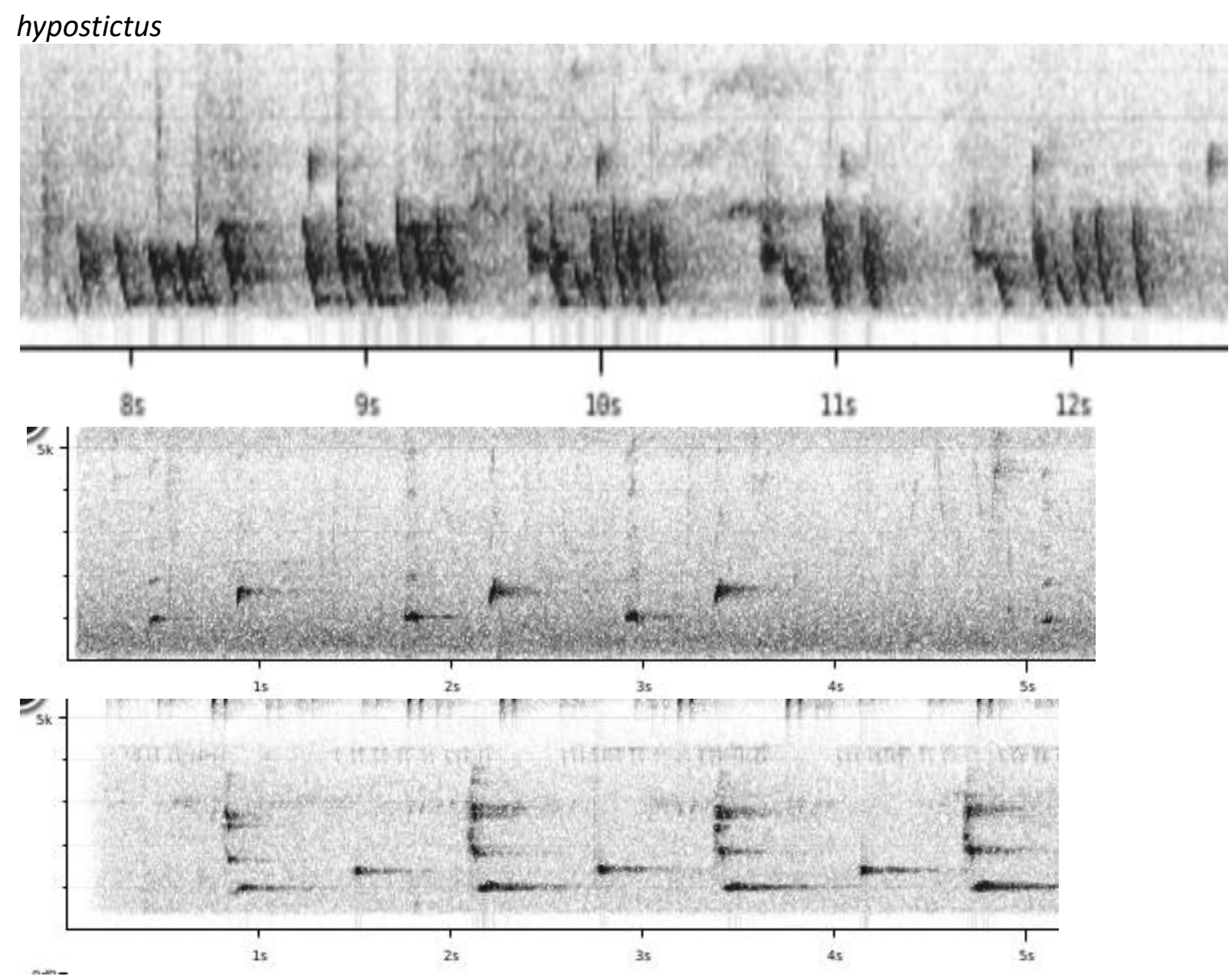




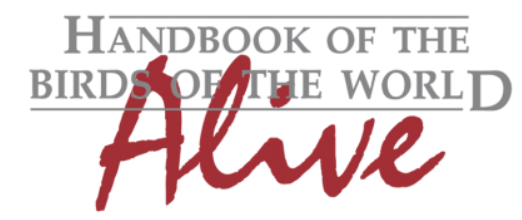

\section{ORNITHOLOGICAL NOTES}
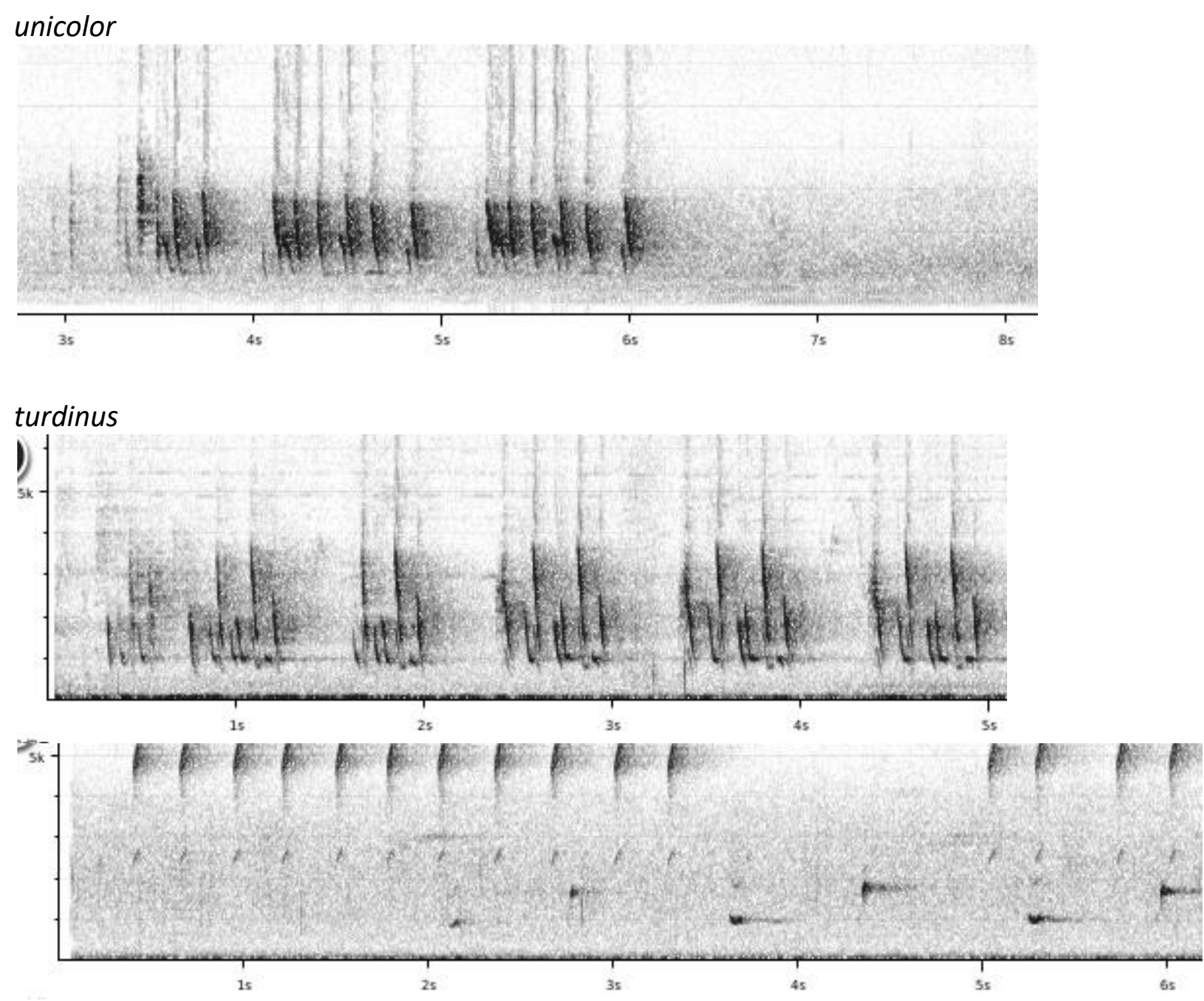

As can be seen from the above examples, voice is quite similar among races, without clear consistent differences at first sight. Frequency range, note length, phrase length and even note shapes in the first song-like vocalization type are nearly identical for the three races. We did not find examples of the second song type for race unicolor however, although it should be said that this is also a less common vocalization in other races.

This note was finalized on 15th April 2016, using sound recordings available on-line at that moment. We would like to thank in particular the many sound recordists who placed their recordings for this species on $\mathrm{XC}$.

\section{References}

Tobias, J.A., Seddon, N., Spottiswoode, C.N., Pilgrim, J.D., Fishpool, L.D.C. \& Collar, N.J. (2010). Quantitative criteria for species delimitation. Ibis 152(4): 724-746. 


\section{Recommended citation}

Boesman, P. (2016). Notes on the vocalizations of Thrush-like Wren (Campylorhynchus turdinus). HBW Alive Ornithological Note 288. In: Handbook of the Birds of the World Alive. Lynx Edicions, Barcelona. (retrieved from http://www.hbw.com/node/1251730 on 12 October 2016). 